процесом, який відбувається протягом чотирьох років навчання. Надана якісна характеристика методики дала змогу визначити вплив кожного з методів та прийомів на розвиток компонентів готовності. Представлену методику підготовки майбутнього менеджера до застосування IT у професійній діяльності ми розглядаємо як систему, яка $\epsilon$ частиною підготовки фахівців 3 управління до професійної діяльності. Перспективу подальших досліджень вбачаємо у проведенні кількісного аналізу результатів формувального експерименту.

\title{
Література
}

1. Генсерук Г. Р. Підготовка майбутніх учителів фізичної культури до застосування інформаційних технологій у професійній діяльності : автореф. дис. на здобуття наук. ступеня канд. пед. наук : спец. 13.00.04 «Теорія і методика професійної освіти» / Г. Р. Генсерук. - Тернопіль, 2005. - 20 с.2. Головань М. С. Використання методу проектів у процесі вивчення інформатики та комп'ютерної техніки в економічному вузі/ М. С. Головань// Теорія та методика навчання математики, фізики, інформатики : зб. наук. пр. : у 3 т. - Кривий Ріг : Вид-во НМетАУ, 2003.Вип. 3. - Т. 3: Теорія та методика навчання інформатики. - С. 67-71.3. Коваль Т. І. Теоретичні та методичні основи професійної підготовки з інформаційних технологій майбутніх менеджерів-економістів : автореф. дис. на здобуття наук. ступеня д-ра пед. наук : спец. 13.00.04 «Теорія і методика професійної освіти»/ Т. І. Коваль. - К., 2008. - 44 с.4. Могилевская Е. В. Профессиональная подготовка будущих менеджеров с использованием имитационного моделирования на основе информационных технологий : дис. ... канд. пед. наук : 13.00 .08 / Екатерина Владимировна Могилевская. - Ставрополь, 2006. - 193 с.5. Пшенична О. С. Модель підготовки майбутнього менеджера організацій до застосування інформаційних технологій / О.С. Пшенична // Вісник Запорізького національного університету: Педагогічні науки. - 2012. - № 2. - С. 142-147.6. Снігур О. М. Формування вмінь використовувати засоби інформаційних технологій у майбутній професійній діяльності вчителя початкової школи : автореф. дис. на здобуття наук. ступеня канд. пед. наук : спец. 13.00.09 «Теорія навчання» / О. М. Снігур. - К., 2007. - 22 с.

УДК 378.14

Антоніна Рибалко

\section{ОПТИМІЗАЦІЯ ВИКЛАДАННЯ ВИЩОЇ МАТЕМАТИКИ В СУЧАСНИХ УМОВАХ}

Рибалко А. П. Оптимізація викладання вищої математики в сучасних умовах.

У статті запропоновано структуру навчального процесу, що дозволить викладачам вищої математики ефективно комбінувати традиційні та інноваційні методи і засоби навчання. Розглянуто особливості впровадження сучасних освітніх технологій 3 урахуванням специфіки предмета. Визначено шляхи оптимізації навчального процесу, обгрунтовано доцільність застосування відповідних методів у викладацькій практиці.

Ключові слова:вища школа, викладання вищої математики, інноваційні методи і засоби навчання, інформаційні комп'ютерні технології, пакети прикладних програм.

Рыбалко А. П. Оптимизация преподавания высшей математики в современных условиях.

В статье предложена структура учебного процесса, позволяющая преподавателям высшей математики эффективно комбинировать традиционные и 
инновационные методы и средства обучения. Рассмотрены особенности внедрения современных технологий обучения с учетом специфики предмета. Определены пути оптимизации учебного процесса, обоснована целесообразность применения соответствующих методов в преподавательской практике.

Ключевые слова:высшая школа, преподавание высшей математики, инновационные методы и средства обучения, информационные компьютерные технологии, пакеты прикладных программ.

Rybalko A. P. Optimization of the teaching of higher mathematics in the present conditions.

The structure of learning process combining traditional and innovational methods and resources in teaching of higher mathematics is proposed in the article. The particular properties of the introduction of modern training technologies specific to the subject are considered. Ways to optimize the learning process are determined, the advisability of using of the corresponding methods in educational practice is justified.

Key words:higher school, teaching of higher mathematics, innovational methods and resources of training, information and computer technologies, application program packages.

Вища математика $є$ нормативною дисципліною для багатьох технічних та економічних спеціальностей. Ї̈̈ вивчення надає систематизованих знань із фундаментальних методів математичного моделювання та дослідження різних процесів, формує в майбутнього фахівця аналітично-дослідницькі компетенції, що є необхідними для спеціаліста в сучасних умовах. Крім того, математика закладає основу для вивчення спеціальних предметів, що відповідають напряму підготовки.

Викладання математичних дисциплін у вищих навчальних закладах завжди стикалось 3 цілою низкою труднощів. Передусім це пов'язано із суттєвою складністю предметів, вивчення яких потребує від студента певних аналітичних здібностей, здатності до логічного мислення, а також достатніх знань i навичок із курсу елементарної математики. Крім того, викладачам завжди доводилось боротися 3 поширеним стереотипом ставлення до математики як до абстрактної, непотрібної в реальному житті науки.

У наш час 3'явились нові проблеми, зумовлені соціально-економічним розвитком суспільства та загальними тенденціями світової освіти. Перш за все, невпинно зростають вимоги до кваліфікації майбутніх фахівців, тому необхідно забезпечити переорієнтацію навчального процесу на отримання професійних умінь, навичок та компетенцій. 3 іншого боку, перехід до кредитно-модульної системи навчання зумовив значні зміни у співвідношенні між аудиторною та самостійною роботою студентів, і викладачам доводиться працювати в умовах катастрофічного дефіциту часу. У зв'язку з цим необхідним $є$ реформування навчального процесу в цілому як щодо організації, так і змістового навантаження.

Найбільшу увагу останнім часом освітянська спільнота приділяє новим підходам та засобам у навчанні. Загальним питанням педагогіки вищої школи присвячено роботи 3. Курлянд, О. Малихіна [3], М. Фіцули [5], В. Нагаєва, Л. Кнодель та ін. 3'явилося багато робіт, присвячених розробленню та питанням упровадження різноманітних інноваційних засобів навчання, застосуванням комп'ютерних інформаційних технологій, серед них роботи Н. Морзе, М.Жалдака [1], С. Семерікова [2], Ю. Рамського, Ю. Триуса та багатьох інших вітчизняних та 
зарібіжних авторів. При цьому питання співвідношення традиційних та новітніх методик у навчанні часто залишаються поза увагою.

Зрозуміло, що у викладацькій практиці надважливо раціонально поєднувати традиційні та інноваційні методи і засоби навчання, особливо під час опанування студентами такої фундаментальної дисципліни, як математика. Для того щоб нововведення не стали самоціллю, під час побудови системи навчання передусім слід керуватися основними дидактичними принципами та іншими засадами педагогічної діяльності. На думку автора, під час створення будь-якого курсу важливо детально продумати пропорційність класичних та новітніх підходів, чітко визначити роль i місце кожного із них з огляду на особливості дисципліни, що викладається.

Mema cmammi - розроблення збалансованої структури навчального процесу 3 позиції оптимального поєднання традиційних та інноваційних підходів під час вивчення математики у вищих навчальних закладах, обгрунтування ефективності іiі застосування.

У світлі вище зазначених цілей, ми розглянемо основні складники навчального процесу і визначимо функціональне навантаження кожної компоненти в сучасних умовах, обговоримо особливості запровадження інноваційних технологій i переформатування традиційних форм навчання під час викладання вищої математики.

Побудова курсу вищої математики повинна починатися із визначення рівня математичної підготовки студентів на момент вступу у вищий навчальний заклад (зазвичай шляхом проведення нульового контролю знань). Для забезпечення систематизованих знань необхідно дотримуватися принципу наступності, тому одним iз завдань викладача $є$ створення умов для опанування дисципліни 3 урахуванням можливих недоліків середньої освіти. Після діагностування лектор повинен доповнити всі компоненти курсу достатнім супроводженням відомостями зі шкільного курсу елементарної математики.

У подальшому ми будемо виходити 3 того, що навчальним планом дисципліни передбачено проведення лекцій, практичних та лабораторних занять, відведено певний час на індивідуальну роботу зі студентами (консультації). На жаль, не завжди вивчення вищої математики супроводжується лабораторними заняттями в комп'ютерних класах. Тим не менш, можна порадити викладачам скористатися рекомендаціями щодо їх проведення в межах практичних занять або самостійної роботи студентів.

Основою будь-якого навчального процесу $є$ курс лекцій. Класична лекція і донині зберігає своє значення як головна ланка дидактичного циклу навчання. Специфікою математичних дисциплін $є$ те, що всі результати не просто декларуються, а отримуються на основі попередніх відомостей. Тому вивчення будь-яких фактів потребує осмислення 3 боку студента, а значить, неможливо переоцінити роль супровідних пояснень викладача. Незамінне також здійснюване методичне перероблення лектором матеріалу, особливо у випадку важких для засвоєння тем. Нарешті, велике значення має і психологічний чинник: будь-який матеріал складається із ланцюга міркувань, має логічну послідовність, тому поступова поява записів викладача на дошці сприймається краще, ніж великий, нехай навіть дуже яскравий блок інформації на слайді, який неможливо осмислити водночас. Тому лекторам не слід захоплюватись презентаціями, коли мова йде про викладання нового матеріалу.

Спілкування між викладачем та студентами під час лекції у свою чергу має важливе виховне значення. Досвідчений лектор супроводжує викладання матеріалу рекомендаціями щодо самоорганізації в навчанні, самодіагностики та самовдосконалення. Особистісний уплив викладача сприяє формуванню світогляду студента, розвитку його 
як особистості та знаходженню свого місця в сучасному суспільстві.

За всієї важливості традиційної лекції продумане введення до навчального процесу сучасних засобів та технологій, безсумнівно сприяє інтенсифікації навчальної діяльності студентів під час опанування теоретичних знань з вищої математики.

Як уже зазначалось, автор уважає, що основний матеріал теми бажано вивчати у класичному стилі, що водночас не заперечує використання презентацій, а відводить їм іншу роль. Комбінування традиційного викладання із презентаціями значно підвищує наочність матеріалу, а значить, і якість його засвоєння. На думку автора, під час викладання вищої математики презентації доречні: для пропедевтики матеріалу; для визначення ключових моментів, основних етапів дослідження (наприклад, у вигляді блок-схем); для ілюстративного супроводження, зображення геометричних аспектів; для узагальнюючих висновків за темою тощо. Сучасні мультимедійні технології надають можливість також використовувати для викладання теоретичного матеріалу повноцінні анімації, звукові та відео супроводження. Безумовно, всі ці засоби значно підвищують якість сприйняття, стимулюють інтерес до предмета загалом.

Окрім комп'ютерних технологій, активізації навчального процесу сприяє проведення лекцій у нетрадиційних формах, серед яких проблемні лекції, лекціїпровокації, лекції-дискусії, лекції-прес-конференції тощо. Запровадження цих навчальних методів актуалізує мотиваційну, стимулювальну, розвивальну, професійно орієнтуючу функції лекцій.

Підсумовуючи вищесказане, автор пропонує таку структуру лекцій-гибридів із вищої математики. Викладання теоретичного матеріалу у класичній формі повинно займати 50-70\% відведеного часу. На презентації та демонстрацію анімаційних роликів відводиться 10-20\% часу. Залежно від змістового навантаження вони можуть розпочинати лекцію, закінчувати іiі, або ж лектор звертається до них кілька разів, супроводжуючи матеріал. Решта аудиторного часу присвячується проведенню одного (чи кількох) із наведених вище нетрадиційних видів робіт. Варіативність форм лекційних занять сприяє як активізації навчання, так і розвитку особистісних якостей студента, його комунікативної компетенції.

У сучасних умовах спеціалістам майже будь-якого технологічного та економічного профілю необхідно мати стійкі навички використання апарата вищої математики для розв'язання задач практичного характеру. У зв'язку з цим суттєво змінюється функціональне призначення практичних занять.

На жаль, значення практичних занять інколи недооцінюється, їм відводиться другорядна роль у навчальному процесі. Таке ставлення має певний деструктивний уплив, особливо на молодих викладачів, отже, миритись 3 цим не можна. Лектор 3 позиції свого авторитету повинен підкреслювати значущість такого типу занять, неможливість їх компенсування іншими видами навчальної діяльності. Дійсно, переорієнтація сучасної вищої освіти 3 процесу навчання на результат вимагає від студента цілеспрямованої праці на отримання практичних навичок і компетенцій, що дозволять йому бути затребуваним та успішним у своїй професійній сфері.

На практичних заняттях 3 вищої математики студент оволодіває навичками аналізу, дослідження та розв'язання широкого спектру задач, вчиться будувати математичні моделі реальних процесів і систем. При первинному опануванні нового матеріалу студентам слід пропонувати завдання абстрактного характеру 3 тим, щоб зосередити увагу на математичних аспектах того чи того інструменту, роз'яснити його властивості, домогтись спроможності його використання. Бажаним результатом $\epsilon$ доведення навичок розв'язання типових завдань до автоматизму. На цей етап 
отримання базових умінь слід виділяти 60-70\% аудиторного часу.

Далі викладач повинен продемонструвати, в якому контексті подібні задачі можуть виникнути в майбутнього фахівця в його професійній діяльності. Усвідомлення застосовності розглянутого математичного апарату $\epsilon$ важливим стимулом для його всебічного вивчення студентами. Крім того, при викладанні будьякого матеріалу необхідно робити посилання на подальше використання його в інших, особливо спеціальних, навчальних курсах.

Упровадження інноваційних форм навчання під час практичних занять не менш виправдане, ніж під час лекцій. Зміна формату, переключення на інший вид роботи попереджає виникнення у студентів перевтоми, стимулює їх інтерес до матеріалу, тим самим значно активізується навчально-пізнавальна діяльність під час заняття. При розгляді окремих питань вельми доречні будуть проблемні заняття, влаштування диспутів, проведення бесід, застосування технології брейнстормінгу тощо. На погляд, автора подібні компоненти практичного заняття сприяють значній інтенсифікації навчання, тому слід планувати відводити на їх проведення 10-15\% загального часу з теми.

Нарешті, надважливо організувати регулярний поточний контроль отриманих знань $\mathrm{i}$ вмінь студентів. Його тестову частину, яку можна (і тому бажано) реалізувати на комп'ютерах, слід перенести на лабораторні заняття. Але в математиці неможливо обмежитись лише тестовими завданнями, тому різним формам контролю, в тому числі виконання домашніх завдань, слід присвятити близько $15 \%$ сумарного аудиторного часу.

Завдяки лабораторним заняттям з вищої математики студенти мають можливість опанувати застосування на практиці значно більшої кількості математичних методів та інструментів, ніж вивчається на практичних заняттях. В одних випадках необхідний математичний апарат $є$ надскладним для аналітичної реалізації через недостатню теоретичну підготовку, в інших - корелюють із надто громіздкими, часоємними розрахунками. Отже, за допомогою лабораторних практикумів розширюється коло прикладних задач, розв'язання яких стає під силу студенту. Крім того, спроможність майбутнього спеціаліста самостійно реалізовувати математичне дослідження та розв'язання проблеми за допомогою комп'ютера $є$ очевидною його перевагою на ринку праці. Для розв'язання численних математичних завдань можуть бути використані такі відомі і поширені пакети прикладних програм, як MatLab, MathCad, Matematica.

Оскільки сам формат заняття на комп'ютері передбачає самостійну роботу, то методичне забезпечення повинно передбачати розроблення індивідуальних завдань для виконання. Також, на думку автора, обов'язково слід включити в план лабораторні роботи студентів в експертних групах, що будуть складати не менше третини від загального навантаження. Постановка завдань у цих випадках повинна відрізнятися загальною метою дослідження, але для його виконання здійснюється в кілька окремих етапів. Результат роботи групи повинен бути презентований студентами, містити обгрунтування можливості та доцільності застосованого математичного апарату, а також витримати захист перед іншими студентами. Оцінювання цього виду робіт враховує не тільки вміння розв'язувати проблему, але й демонструвати отримані результати.

Завдяки організації лабораторних занять 3 вищої математики за визначеною схемою студент отримує цілу низку важливих професійних та комунікативних компетентностей: здатність самостійно обирати методи і засоби дослідження; вміння реалізовувати алгоритми за допомогою програмного забезпечення; здібність до творчого підходу та креативного мислення; здатність до ефективної співпраці під час 
розв’язання поставлених задач та організації роботи групи спеціалістів тощо.

Отже, запропонована структура навчального процесу в контексті опанування дисципліни «Вища математика» дозволяє розв'язувати цілий комплекс специфічних і загальних проблем сучасної вищої школи. Оптимальне комбінування традиційних та інноваційних форм наближає розв'язання таких злободенних стратегічних задач національної освіти, як підвищення іiі доступності, якості та конкурентоспроможності [4, с. 2].

Подальшого дослідження потребує конкретизація розглянутих засад на окремі теми та розділи дисципліни, розроблення необхідного методичного забезпечення, деталізація таких аспектів, як оцінювання, організація самостійної роботи студентів тощо. Нарешті, невпинний розвиток інформаційних комп'ютерних технологій дозволить і надалі вдосконалювати навчальні програми математичних дисциплін у вищих навчальних закладах.

\section{Література}

1. Жалдак М. І. Комп'ютерно-орієнтовані засоби навчання математики, фізики, інформатики : [посіб. для вчителів] / М. І. Жалдак, В. В. Лапінський, М. І. Шут. - К. : НПУ ім. М. П. Драгоманова, 2004. - 182 с. 2. Інноваційні інформаційно-комунікаційні технології навчання математики : [навч. посіб.] / В. В. Корольський, Т. Г. Крамаренко, С. О. Семеріков, С. В. Шокалюк; за ред. М. І. Жалдак. - Кривий Ріг : Книжкове вид-во Кирєєвського, 2009. - 334 с.3. Методика викладання у вищій школі : [навч. посіб.] / О. В. Малихін, І. Г. Павленко, О. О. Лаврентьєва, Г. І. Матукова. - Кривий Ріг : КДПУ, 2010. - 270 с. 4. Національна стратегія розвитку освіти в Україні на 2012-2021 роки [Електронний ресурс]. - Режим доступу :http://www.mon.gov.ua/images/files/news/ 12/05/4455.pdf 5. Фіцула М. М. Педагогіка вищої школи : [навч. посіб.] / М. М. Фіцула. - [2-е вид., доп.] - К. : Академвидав, 2010. - 454 с.

УДК 378

Вікторія Ткачук

\section{РОЗВИТОК ІКТ-КОМПЕТЕНТНОСТІ МАЙБУТНІХ ІНЖЕНЕРІВ-ПЕДАГОГІВ У ВНЗ УКРАЇНИ}

Ткачук В. В. Розвиток ІКТ-компетентності майбутніх інженерів-педагогів у ВНЗ України.

У статті розглянуто поняття компетентності інженера-педагога, визначено умови, що необхідно забезпечити для підвищення якості освіти з упровадженням IКТ. Акцентовано на ІКТ-компетентності, як такій, що $є$ ключовою для студентів інженерно-педагогічного профілю в сучасному інформаційному суспільстві. Ураховано позицію, що розвиток ІКТ-компетентності майбутніх інженерів-педагогів відбувається у процесі вивчення інформатичних дисциплін, відповідно розглянуто програму навчального курсу «Комп’ютерні технології в навчальному процесі» для напряму підготовки 6.010104 «Професійна освіта (за профілем)».

Ключові слова:компетентності інженера-педагога, ІКТ-компетентність, шляхи розвитку ІКТ-компетентності майбутнього інженера-педагога.

Ткачук В. В. Развитие ИКТ-компетентности будущих инженеров-педагогов в вузах Украины.

В статье рассмотрено понятие компетентности инженера-педагога, определены условия, которые необходимо обеспечить для повышения качества образования с внедрением ИКТ. Акцентировано на ИКТ-компетентности, как таковой, которая является ключевой для студентов инженерно-педагогического профиля в современном информационном обществе. Учтено, что развитие ИКТ-компетентности 